V. Khilchevskyi, Dr.Sc.,Geography, Professor

Taras Shevchenko National University of Kyiv, Kyiv, Ukraine

\title{
GLOBAL WATER RESOURCES: CHALLENGES OF THE 21st CENTURY
}

The article provides an analytical overview of the state of global water resources and their use in the world. The focus is on the most important component of water resources - fresh water, which on the planet is only $2.5 \%$ of the total. The most accessible renewable water resources are river runoff, which is distributed unevenly on the surface of the planet: Asia (32\%), South America (28\%), North America (18\%), Africa (9\%), Europe (7\%), Australia and Oceania (6\%). Along with the characteristics of the known components of freshwater resources (river runoff, groundwater, glaciers), attention is also focused on trends in attracting unconventional sources (recovered wastewater or gray water, desalinated, specially collected rainwater).

The total use of fresh water in the world is only $9 \%$ of the total river flow of the planet. At the same time, the problem of water scarcity was included in the list of the World Economic Forum 2015, as one of the global risks in terms of potential impact on human society in the next decade. Among the causes of global water scarcity are geographical and socio-economic.Geographical reasons are the spatial and temporal (seasonal) mismatch of the demand for fresh water and its availability. Socio-economic reasons are the growth of the world's population, urbanization, improving living standards, changes in consumption patterns and an increase in irrigated land. The latter have become key in the growth of global water demand.

Experts forecast that the limited access to fresh water in 2050 can be felt by 3.3 billion more people than in 2000. The article gives examples of a methodology for hydrological assessment of water scarcity (calculation of the ratio of the volume of annual renewable water resources to the population) and the methodology of economic and geographical assessment. Other approaches to assessing water resources by creating new paradigms (water - blue, green, virtual, water footprint) have been characterized.

Throughout the history of mankind, there have been many conflicts related to water. Active water cooperation between countries today reduces the risk of military conflicts. This conclusion was made after studying transboundary water relations in more than 200 joint river basins, covering 148 countries. The right to safe water and sanitation is a fundamental right of everyone (UN, 2010). Therefore, among the 17 sustainable development goals adopted by the UN for implementation for the period 2015-2030, Global Goal 6 "Clean Water and Good Sanitary Conditions" is aimed at ensuring sustainable management of water resources and sanitation for all. This will save people from diseases, and society will be given the opportunity to be more productive in economic terms.

Keywords: water resources, fresh water, alternative sources of water resources, water use, water stress, water scarcity, recovered water, gray water, blue water, green water, virtual water, water footprint

http://doi.org/10.17721/1728-2721.2020.76-77.2

УДК 911.3

K. Мезенцев, д-р геогр. наук, профр. ORCID iD: 0000-0003-1974-7860 Scopus ID: 57192031428

WoS Researcher ID: M-2537-2018,

Н. Провотар, канд. геогр. наук, доц. ORCID iD: 0000-0003-2211-6509

Scopus ID: 57204288896

WoS Researcher ID: AAC-3776-2020,

В. Паренюк, асп.

Київський національний університет імені Тараса Шевченка, Київ, Україна

\section{ЕКОНОМІЧНІ ФАКТОРИ РЕГІОНАЛЬНОӤ ДИФЕРЕНЦІАЦІЇ БЕЗРОБІТТЯ ТА МІГРАЦІЙНИХ НАМІРІВ МОЛОДІ В УКРАЇНІ}

Міграційні наміри молоді пов'язані із ситуацією на молодіжному ринку праці, доходами населення та інвестиційноінноваційними процесами. Такі економічні чинники, у свою чергу, зумовлюють ситуацію на регіональних ринках праці. Трудова та освітня міграція молоді становлятьть загрозу втрати населення найактивнішого віку та найвищого рівня освіти, а отже подальшу демографічну кризу, втрати трудоресурсного потенціалу та загострення проблеми дефіциту кваліфікованих кадрів на регіональних ринках праці в Україні. У статті наведено результати дослідження економічних факторів регіональної диференціації безробіття молоді в Україні в контексті їі міграційних намірів. Інформаційною базою дослідження є дані Державної служби статистики України, зокрема показники рівня безробіття молоді, середньомісячної заробітної плати, наявних доходів та витрат на одну особу, структури доходів, обсягу інвестицій в основний капітал на одну особу за регіонами України за період 2000-2018 рр. Методом рангів здійснено групування регіонів України з виділенням груп регіонів із різним рівнем доходів та обсягу інвестицій в основний капітал на одну особу, розроблено картосхеми групування регіонів України. Місто Київ та столична область незмінно лідирують як за показниками інвестицій, так і за доходами й видатками. Стабільно відставали в 2001-2018 рр. регіони Західної України - Рівненська, Тернопільська, Чернівецька та Закарпатська області. Кореляційний аналіз виявив залежність рівня безробіття молоді від інвестиційної привабливості та фінансової спроможності населення (включаючи показники середньомісячної заробітної плати, доходів і витрат на одну особу) в Україні. Однак така залежність характеризується значними регіональними відмінностями, які не можна пояснити рівнем розвитку, розташуванням або спеціалізацією регіонів. Визначено, що вплив економічних факторів є більш складним та, імовірно, пов'язаний із конкретними стратегіями місцевої влади щодо розв'язання проблем молодіжного безробіття. Тому навіть зростання інвестиційної привабливості та фінансової спроможності населення не гарантує послаблення міграційного відтоку молоді з країни.

Ключові слова: безробіття молоді, ринок праці, міграційні наміри, регіональна диференціація, Україна.

Постановка проблеми. Міграційні наміри та міграційна поведінка молоді взаємопов'язані із ситуацією на молодіжному ринку праці, зокрема рівнем безробіття, доходами населення та інвестиційно-інноваційними процесами в економіці. Між міграцією та ринком праці є двосторонній зв'язок: регіональні ринки праці визначають напрями міграції, а переміщення людей впливають на їхній стан [9].

Сучасними тенденціями на світовому ринку праці, пов'язаними із міграційними процесами, є глобалізація руху робочої сили, циркулярний характер трудових міграцій, виникнення "транснаціональної робочої сили", зростання обсягів нелегальної трудової міграції, кількості шукачів притулку та біженців, сегментація ринку праці, в межах якого сформувалися професійні, вікові, гендерні, регіональні сегменти [3]. Світовий молодіжний ринок праці характеризується такими рисами: зниженням рівня зайнятості молоді (з 46,4 \% у 1999 до $41,2 \%$ у 2019 р. [23]); збільшенням частки молоді, яка здобуває освіту (із 59 \% у 1999 до 76 \% у 2018 р. [20]), 
що відбувається, зокрема, завдяки збільшенню тривалості навчання; зростанням рівня неформальної зайнятості молоді (понад три чверті працюючої молоді має неформальну зайнятість [23]); вищим рівнем безробіття серед молоді порівняно із загальним показником безробіття; нестабільними умовами праці та недостатнім рівнем соціального захисту (близько третини молоді, що працює, проживає в умовах помірної та крайньої бідності [23]; вищим рівнем вразливості молоді на ринку праці в періоди економічних криз порівняно з іншими категоріями населення. Вони характерні і для молодіжного ринку праці України. Дослідження підтверджують посилення еміграційних настроїв молодих українців, мотиваторами яких є: фрізична та соціальна безпека, саморозвиток через опанування знань і навичок та фрінансовий добробут [12, с. 63]. Саме тому актуальним залишається дослідження економічних чинників, які зумовлюють ситуацію на регіональних ринках праці України та міграційну поведінку молоді, адже трудова й освітня міграція несуть загрозу втрати населення найактивнішого віку та найвищого рівня освіти, а отже подальшу демографічну кризу, втрати трудоресурсного потенціалу та загострення проблеми дефіциту, насамперед, кваліфікованих молодих кадрів на регіональних ринках праці в Україні.

Аналіз останніх досліджень і публікацій. Міграційну поведінку населення в сучасному світі пояснюють дві групи концепцій. Перші - спрямовані на обґрунтування причин міграції (зокрема, концепція людського капіталу та міграцій, концепція дуального ринку праці й міграцій, концепція глобалізації світового господарства та міграцій, концепція соціальних міграційних мереж, а також узагальнююча модель фракторів "виштовхуванняпритягання"); другі намагаються пояснити фактори та напрями взаємодії мігрантів із територіальним соціумом, до якого вони приїжджають (зокрема, концепції адаптації, соціальної інтеграції, культурної асиміляції, належності, "якорування" мігрантів тощо) [4].

Визначальними чинниками трудової міграції в Україні $€$ глобалізація, кон'юнктура на світовому та національному ринках праці, трудоресурсний потенціал, рівень і якість життя населення, геополітичні процеси тощо. Дослідники міграції з Інституту регіональних досліджень імені М I. Долішнього НАН України зазначають, що поруч із економічними чинниками міграції, які кількісно вимірюються середнім розміром заробітної плати, рівнем цін у країні, якістю життя населення, наявністю робочих місць, стабільним розвитком економіки, виділяють соціальнокультурологічні та політичні (стабільність політичної системи, розвиток демократії, відсутність корупції та воєнних конфліктів). Проте наявність саме економічних розривів в розвитку окремих регіонів призводять до запуску трансформаційних процесів у регіонах та фрормування міграційних систем різного рівня і форм [5, с. 70].

Економічні чинники трудової міграції в Україні діють у певному ментальному середовищі, що посилює чи послаблює їхній вплив [13, с. 48]. Імовірно, в Україні, передусім, у західних областях, діє дуже важливий чинник міграційного потенціалу - демонстраційна успішність самої міграції [13, с. 45].

Україна програє країнам-сусідам за рівнем споживчих можливостей і матеріального становища в цілому, що продовжує збільшувати ризики відтоку активної частини населення за кордон, а з урахуванням того, що більшість країн-сусідів потребують додаткової робочої сили для підтримки темпів економічного зростання, вплив цих аспектів на міграцію стає вирішальним [13, c. 48]. Зокрема, половина безробітних $€$ потенційними мігрантами, а приблизно кожен п'ятий належить до категорії "твердих" мігрантів [5, с. 89].

Молодь $є$ чисельною та найперспективнішою складовою ринку праці й виконує ряд важливих соціально-економічних функцій у державі. Водночас на ринку праці молодь залишається одним із найменш захищених сегментів. Насамперед, це стосується рівня безробіття та низької оплати праці, що породжує цілу низку соціально-економічних проблем [7].

Серед головних причин трудової та освітньої міграції молоді найчастіше називають неефективну молодіжну політику в Україні, порівняно високий рівень безробіття серед молоді, неможливість знайти роботу за фахом, бажання молоді здобути диплом європейського зразка [20]. Істотною причиною молодіжного безробіття $€$ недостатня пропозиція фрахових робочих місць і низький рівень заробітної плати на першому робочому місці за фрахом на початку кар'єрного шляху. В Україні таке явище можна частково пояснити значною кількістю вищих навчальних закладів, низьким рівнем поінформованості абітурієнтів про стан і динаміку ринку праці та попит на конкретні спеціальності, вибором "престижних" спеціальностей без урахування реальних можливостей працевлаштуватися після закінчення навчання. Саме тому молодь становила третину серед безробітних в Україні [4].

Сучасні концепції міграційної поведінки пов'язані переважно з економічними та соціально-психологічними теоріями. Але роль відстані, простору, регіональних особливостей залишає їх у полі географрічного трактування [10].

Згідно з неокласичною теорією міграції, ключовим ії чинником $є$ заробітна плата, а рішення про міграцію приймається на основі очікуваної різниці в доходах [14]. Наслідки такої міграції є позитивними для обох сторін, оскільки, з одного боку, мігранти частину доходів переказують у країну свого походження і покращують економічну ситуацію в ній, а з іншого боку, приймаюча країна задовольняє свій попит на робочу силу, створюючи додатковий поштовх для економічного зростання.

Нова економічна теорія міграцій стверджує, що рішення про міграцію приймається не індивідуально, а в колі сім'ї, тому міграція не завжди пов'язується з більшим заробітком. Таким чином, міграція $€$ не лише засобом максимізації доходів домогосподарств, а можливістю диверсифрікувати ці доходи [22].

Мережева теорія міграцій акцентує увагу на тому, що наявність міжособистісних міграційних мереж у приймаючій країні допомагає мігрантам у багатьох аспектах повсякденного життя, у т. ч. зменшенні витрат (не тільки грошових, але й психологічних) та міграційних ризиків, а також полегшенні процесу самої міграції [21].

Відповідно до теорії людського капіталу, кожна окрема особа приймає рішення про міграцію на основі розрахунку прибутку від використання переваг власного людського капіталу в країні призначення. При цьому вираховуються затрати на міграцію, проживання та адаптацію. Ці прибутки мають бути вищими, ніж очікувані у країні походження. Лише у такому випадку міграція є доцільною. Характеристиками людського капіталу, що визначають рішення про міграцію тієї чи іншої особи, $є$ стать, вік, освіта, досвід роботи, мовні компетенції [15]. Згідно з теорією людського капіталу вважається, що молодь більш схильна до міграції. Це пояснюється тим, що 
в молоді порівняно більше часу для кар'єри, тому молоді люди відповідно отримають більше переваг від переїзду за кордон. Окрім цього, молодь значно менше інвестувала (зокрема, у вигляді податків) у країну походження, ніж населення старших вікових категорій, що також впливає на рішення про міграцію [16].

Е. Лі сформулював модель факторів виштовхуванняпритягування мігрантів (push-pull model of migration). $\mathrm{Y}$ ній міграція розглядається як функція відносної привабливості/непривабливості районів походження (виїзду) та призначення (в"їзду) мігрантів. Переважання несприятливих умов (push-фракторів) в одному районі (напр., високий рівень безробіття, низька заробітна плата тощо) "виштовхують" людей із місця проживання, а переважання сприятливих умов іншого району (рull-фракторів) "притягують" їх. При цьому різні люди по-різному сприймають фрактори "виштовхування - притягування" [10].

Г. Енгберсен увів поняття "ліквідної" міграції (liquid migration) для означення процесу, коли мігранти обирають індивідуалізовані шляхи міграцій та шукають нові місця для роботи і проживання, користуючись відкритими кордонами та ринками праці. Їхнє перебування за кордоном не спрямоване на підтримку членів сім'ї вдома. Вони цілком зосереджені на власній кар'єрі [17]. Міграції студентів розглядають саме з точки зору "ліквідної" (плавної, нестійкої) міграції.

За сучасних умов домінування процесів глобалізації та економічної інтеграції все більшої популярності набуває циркулярна міграція. IІЇ сутність можна охарактеризувати як постійну, довгострокову та повторювану міграцію. Підґрунтям для неї $€$ тісні економічні зв'язки між країною походження та країною призначення, які часто формують єдиний економічний простір і мають спрощенні умови перетину кордону, що підвищує загальну мобільність населення на світових ринках праці [24].

Мета дослідження. Ураховуючи вищесказане, метою дослідження визначено аналіз економічних факторів, які зумовлюють безробіття молоді на регіональних ринках праці України, та оцінку зв'язку економічних індикаторів із рівнем безробіття молоді в регіонах України в контексті міграційних намірів молоді. Дослідницькими питаннями були визначені такі: якою $є$ регіональна диференціація економічних чинників безробіття та міграції молоді в Україні у 2000-х роках; чи існує зв'язок між рівнем безробіття молоді та доходами й витратами населення, інвестиційною привабливістю регіонів України в період 2000-2018 рр.; як виявляється вплив економічних факторів на рівень безробіття на регіональних ринках праці молоді та її міграційні наміри.

Методика та методологія. Інформаційну базу дослідження фрормують дані Державної служби статистики України. Зокрема, обрано показники рівня безробіття молоді, середньомісячної заробітної плати, наявних доходів і витрат на одну особу, обсягу інвестицій в основний капітал на одну особу за регіонами України за період 20002018 рр. У розрахунках не враховувалися статистичні дані по АР Крим, Донецькій та Луганській областях у зв'язку із відсутністю частини даних за період 2014-2018 рр.
У дослідженні регіональної диференціації наявних доходів на одну особу та обсягу інвестицій в основний капітал на одну особу використано метод рангів, результатом чого стало групування регіонів України з виділенням груп із різним рівнем доходів та обсягу інвестицій в основний капітал на одну особу. Також використано картографрічний метод дослідження для візуалізації динаміки різних економічних індикаторів та результатів групування регіонів України. Метод кореляційного аналізу використано для визначення тісноти зв'язків між показником рівня безробіття молоді та показниками середньомісячної заробітної плати, доходів та витрат на одну особу, обсягу інвестицій в основний капітал на одну особу за регіонами України у період 2000-2018 pр.

Виклад основного матеріалу. Економічний аспект впливу макросередовища на ринок праці традиційно розглядають через призму економічної ситуації в країні, piвень зайнятості й безробіття, рівень доходів населення, інвестиційний клімат, стабільність національної валюти [5, с. 65]. Як правило, при зростанні рівня життя населення регіон чи окреме місто, агломерація, метрополітенський регіон стають осередками притягання мігрантів. I навпаки, при зниженні рівня життя з регіону спостерігається відтік населення, насамперед, молодого віку.

Для оцінки рівня життя населення ми використали ряд економічних індикаторів: середньомісячна заробітна плата, доходи та витрати на одну особу, структура доходів населення, обсяг інвестицій в основний капітал на одну особу, частка промислових підприємств, що впроваджували інновації.

Україна належить до країн із рівнем доходів нижче середнього (група країн із валовим національним доходом 1036-4045 дол. США). У 2019 р. ВВП на душу населення в Україні становив 3660 дол. США [18].

Аналіз доходів на одну особу за регіонами України у 2001-2018 рр. дав можливість виділити такі ознаки: регіоном із найвищим показником незмінно було м. Київ; до групи регіонів-лідерів також входили Донецька, Дніпропетровська, Запорізька, Харківська та Полтавська області. У 2001 р. чотири регіони Західної України (Закарпатська, Івано-Франківська, Чернівецька і Тернопільська області), а також Херсонська область входили до групи 3 найгіршими показниками. Десять регіонів (в основному, Центральної та Західної України) входили до групи з низькими показниками. Тобто дві третини регіонів України мали найнижчі та низькі показники заробітної плати. У 2010 р. таких регіонів було вже 13, у 2018 - вісім. Однак, шість із восьми - це регіони Західної України, що свідчить про перманентну проблемну і невирішувану соціально-економічну ситуацію в них.

Найбільший обсяг витрат на одну особу характерний для населення м. Києва та Київської області. Так, у 2018 р. витрати жителів Києва перевищили витрати жителів Тернопільської області, де показник найнижчий, утричі. Порівняно з рештою регіонів витрати жителів Києва більші у 2-2,5 рази. Окремо слід указати на Луганську та Донецьку області, де після початку збройної агресії Російської Федерації витрати населення стали нижчими, ніж були до 2014 р. 


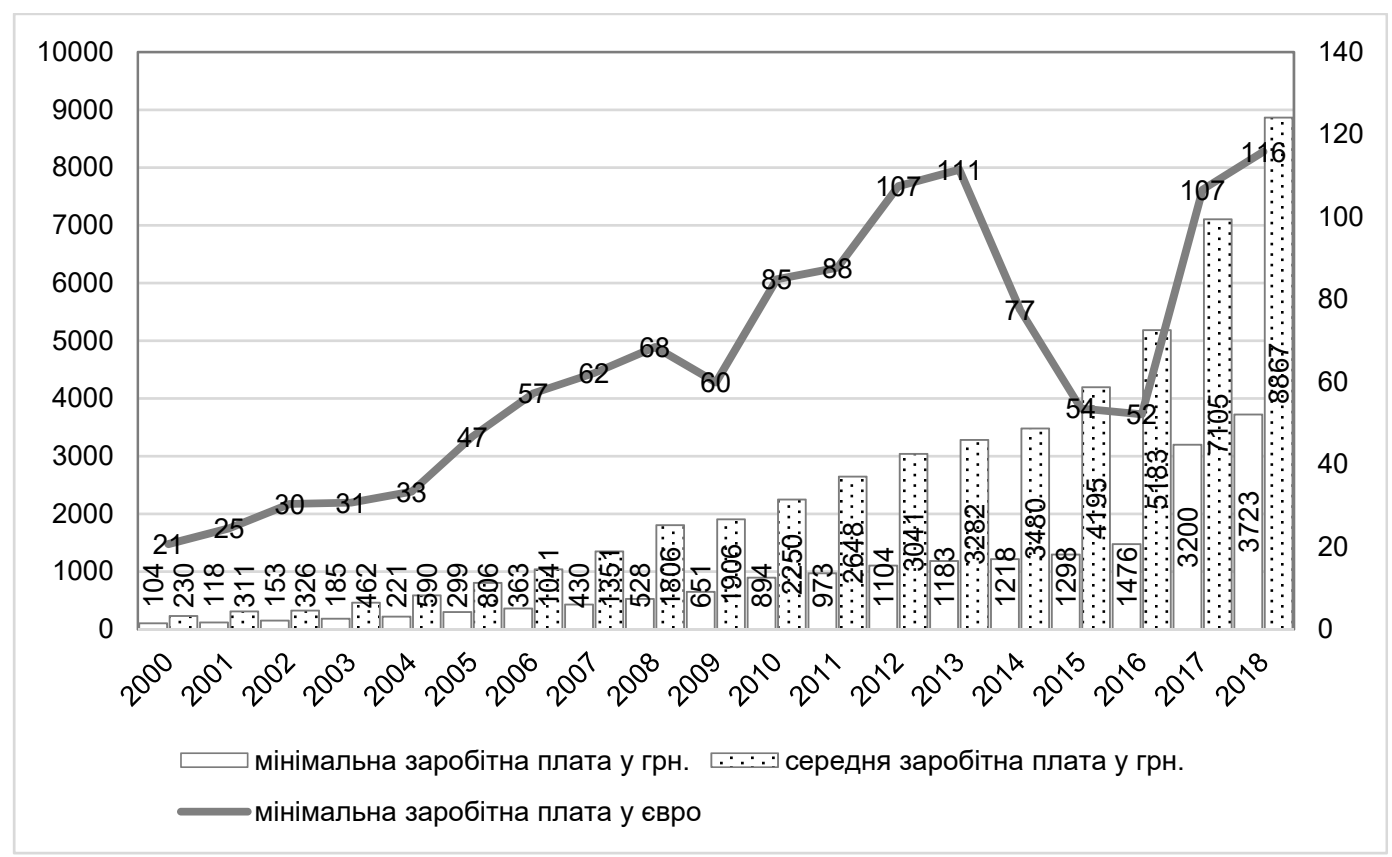

Рис. 1. Динаміка мінімальної та середньої місячної заробітної плати в Україні у 2000-2018 рр. (за даними [1])

Наріжним каменем ефективної зайнятості в Україні та важливим показником, за яким характеризують ринок праці, $є$ оплата праці [5]. На рис. 1. зображено динаміку мінімальної та середньої заробітної плати в Україні у 2000-2018 рр. Оскільки купівельна спроможність гривні суттєво змінювалась, окремо позначено мінімальну заробітну плату в міжнародній резервній валюті - євро. Упродовж досліджуваного періоду в усіх регіонах України зростала як мінімальна, так і максимальна заробітна плата в гривні в абсолютних вимірах. Дані перераховані в євро дають підставу умовно виділити два періоди цього процесу: період 2000-2013 рр., що характеризувався постійним зростанням (загалом у п'ять разів) мінімальної заробітної плати за винятком 2009 р. (вияв негативних наслідків світової фрінансової кризи); період 20142018 рр., що характеризувався різким спадом (удвічі за два роки) і таким самим різким зростанням заробітної плати у 2017-2018 рр. до докризового рівня.

Однак у цілому середня заробітна плата в Україні $є$ приблизно в чотири рази нижчою порівняно з Польщею, Естонією, Литвою чи Словаччиною; із Німеччиною у 2018 р. різниця була більше ніж у 12 разів. Визначення впливу на формування міграційного потенціалу такого чинника, як рівень життя, не зводиться до оцінки різниці в рівні зарплат. Без урахування всіх джерел надходжень, це викривлює уявлення про справжній потенціал привабливості рівня доходів у різних країнах. Важливим чинником, що корегує вплив на рівень життя загальних доходів населення, $є$ рівень цін на споживчі товари й послуги [13, с. 42].

Найбільшу частку офіційних доходів населення у регіонах України становить заробітна плата, частка якої була найнижчою у 2009-2015 рр. (близько $40 \%$ ). Водночас значну частину доходів населення України становлять соціальні допомоги та інші одержані поточні трансферти (далі соціальні допомоги). За досліджуваний період частка соціальних допомог у цілому зменшилась на 3,5\%, але у "кризовий період" 2009-2015 рр. вона зростала. Так, у 2009 р. частка соціальних допомог у структурі доходів в Україні дорівнювала частці заробітної плати. Частка двох інших складових структури доходів - прибутку та змішаного доходу і доходу від власності - змінювалась не суттєво. У цілому структура доходів населення в Україні, в якій частка соціальних допомог фактично приблизно дорівнює частці заробітної плати, свідчить про низький рівень заробітної плати та суттєву залежність добробуту населення від державних соціальних виплат.

В Україні існує доволі суттєва регіональна диференціація частки заробітної плати у структурі доходів населення (рис. 2). Так, у м. Києві частка заробітної плати є найвищою та становила у 2018 р. 60 \%, понад половину доходів заробітна плата становила в Донецькій, Дніпропетровській та Луганській областях. Натомість частка заробітної плати у доходах населення менше 40 \% характерна для Івано-Франківської, Тернопільської, Херсонської, Хмельницької та Чернівецької областей.

Доходи населення важливі стосовно формування середнього класу в регіонах України як прошарку населення з достатнім для задоволення своїх потреб рівнем доходів, високим кваліфікаційно-освітнім рівнем, що відіграє ключову роль у підтримці стабільності у суспільстві.

Важливою складовою соціально-економічного розвитку регіонів і рівня життя населення $€$ інвестиційна та інноваційна діяльність. Інвестиції позитивно впливають на соціально-економічний розвиток регіонів шляхом підвищення ефективності економічної діяльності, доходів та рівня зайнятості. У період із 2014-2018 рр. обсяги інвестицій в основний капітал в Україні мали позитивну динаміку (зросли у понад 2,5 рази). У той же час, для України характерна суттєва диференціація обсягу інвестицій в основний капітал за регіонами України, особливістю якої $€$ концентрація інвестицій у кількох регіонах із найвищим рівнем соціально-економічного розвитку. Це призводить і надалі буде призводити до поглиблення розриву соціально-економічних індикаторів регіонального розвитку та посилення кризових соціально-економічних явищ у регіонах, які отримують незначні обсяги інвестицій в основний капітал для розвитку інноваційних галузей економіки, їхньої модернізації, створення нових робочих місць тощо. Такий стан речей спонукатиме активну частину населення, насамперед молодь, до пошуку кращих умов життя і працевлаштування за межами таких регіонів, в обласному центрі чи за кордоном. 


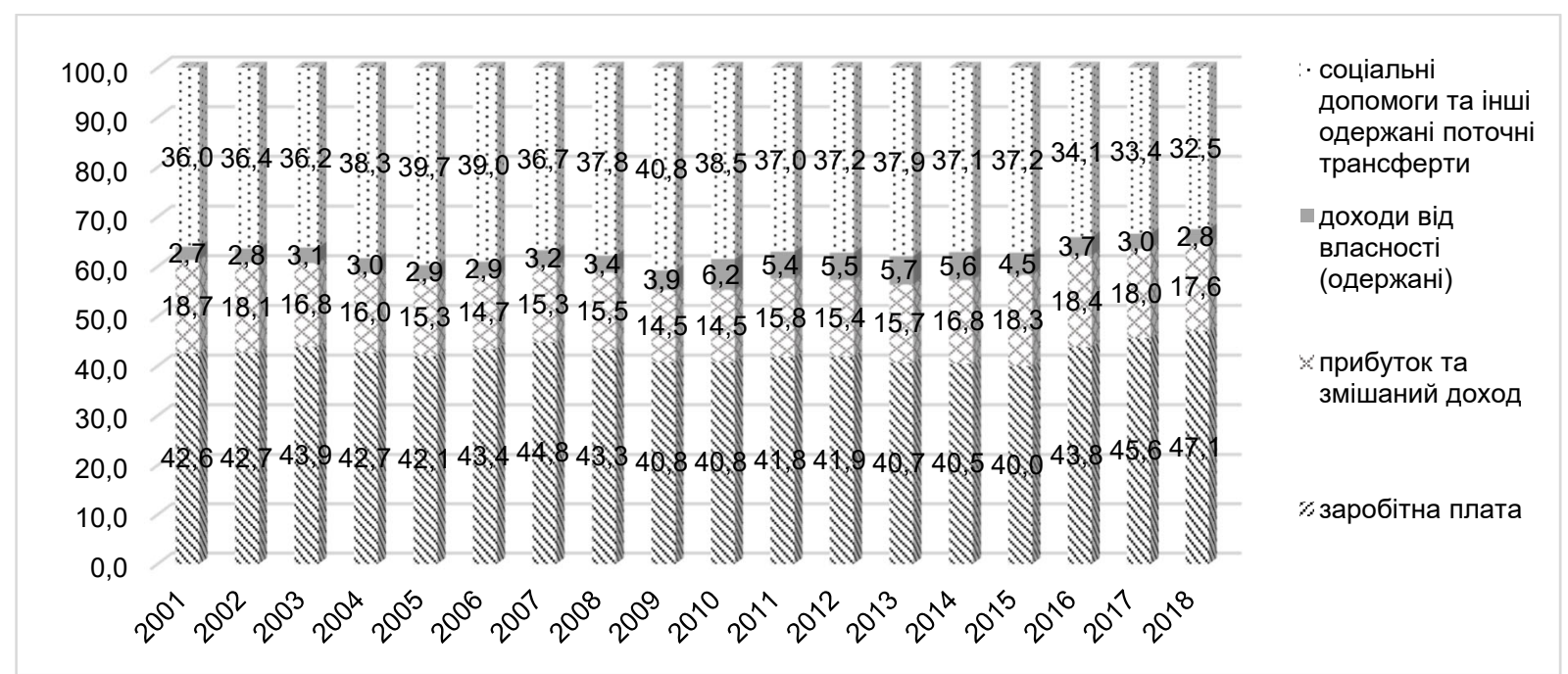

Рис. 2. Динаміка структури доходів населення України у 2000-2018 рр. (за даними [1])

У 2018 р. обсяг інвестицій на одну особу в м. Київ був у 46 разів більшим, ніж у регіоні з найгіршим показником - Луганській області. Розрив в обсязі інвестицій на душу населення Києва та Київської області, що займала другу позицію, перевищував триразово. Унаслідок бойових дій на території Донецької та Луганської областей обсяг інвестицій у 2014 р. скоротився у два та три рази відповідно. При цьому, якщо в Донецькій області поступово ситуація покращується, то в Луганській області залишається критичною, регіон має найнижчі показники обсягу інвестицій в основний капітал на душу населення протягом 2014-2018 рр.

Методом рангів здійснено групування регіонів України за наявними доходами та обсягом інвестицій в основний капітал у розрахунку на одну особу у 2001-2018 рр. і виділено такі групи (рис. 3, 4):

За наявними доходами на одну особу:

- Волинська, Рівненська, Тернопільська, Івано-Франківська, Чернівецька, Закарпатська, Черкаська, Кіровоградська, Херсонська області з найнижчим рівнем;

- Житомирська, Хмельницька, Вінницька, Одеська, Чернігівська області з низьким рівнем;
- Львівська, Миколаївська, Сумська, Полтавська та Харківська області із середнім рівнем;

- Київська, Дніпропетровська та Запорізька області 3 високим рівнем;

- місто Київ з найвищим рівнем.

За обсягом інвестицій в основний капітал на одну особу:

регіони з тривалим у часі низьким обсягом: Закарпатська, Рівненська, Житомирська, Тернопільська, Чернівецька, Вінницька, Чернігівська, Сумська та Херсонська області;

регіони із тривалим у часі середнім обсягом: Волинська, Львівська, Івано-Франківська, Хмельницька, Черкаська, Кіровоградська, Миколаївська, Запорізька області; регіони із тривалим у часі високим обсягом: Київська, Одеська, Полтавська, Харківська, Дніпропетровська області;

регіон із найвищим обсягом: м. Київ.

Особливу групу формують Донецька і Луганська області та АР Крим, в якій порівняльні статистичні дані представлені в динамічному ряду за період 20012013 рp. Із 2014 р. статистичні дані по Донецькій та Луганській областях розраховані лише по частині території, яка підконтрольна Україні, а дані по АР Крим відсутні.

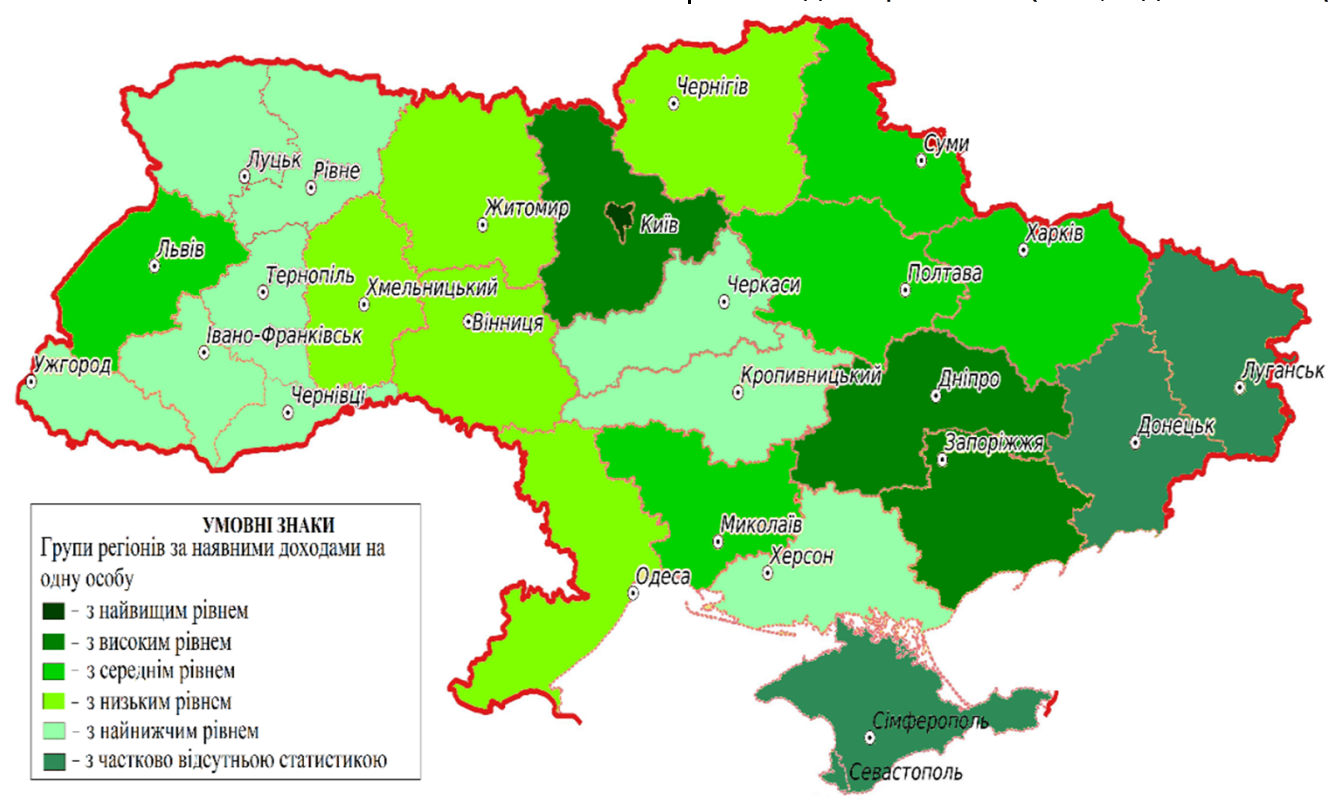

Рис. 3. Групи регіонів України за наявними доходами на одну особу у 2001-2018 рр. (за даними [1]) 


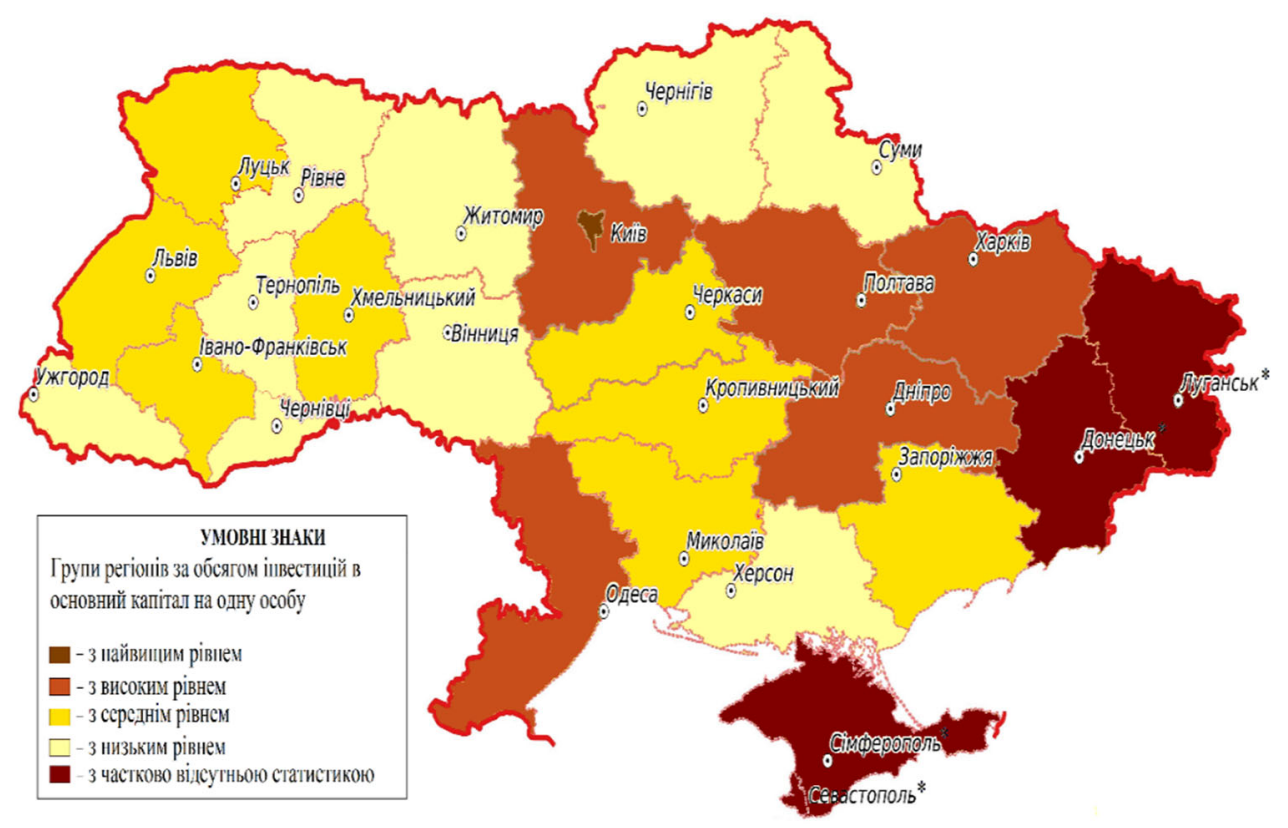

Рис. 4. Групи регіонів України за обсягом інвестицій в основний капітал на одну особу в 2000-2018 рр. (за даними [1])

У 2018 р. частка промислових підприємств, що впроваджували інновації (продукцію та/або технологічні процеси) в Україні, становила 15,6 \% від загальної кількості зареєстрованих промислових підприємств і була найвищою у м. Києві, Харківській та Дніпропетровській областях [6]. У цілому частка реалізованої інноваційної продукції в Україні в 2018 р. була дуже низькою $(0,7 \%)$, із найвищими частками в Запорізькій та Харківській областях. У Хмельницькій області така продукція взагалі не вироблялась [6]. Ці дані свідчить про концентрацію промислових інноваційно активних підприємств лише в трьох регіонах України і критично недостатню їхню кількість в інших регіонах. Такий розподіл негативно позначається на соціально-економічному розвитку регіонів і, відповідно, рівнях безробіття, оплати праці й міграціях населення в пошуках вищих доходів та місця роботи.

Якщо проаналізувати зв'язок рівня безробіття молоді в Україні з показниками, що відображають вплив економічних чинників (попередньо переведені в ціни 2001 р.) у період 2001-2018 рр., то можна виявити такі особливості. Найтісніше динаміка безробіття молоді пов'язана 3 інвестиційною привабливістю території (інвестиції в основний капітал у розрахунку на одну особу): коефіцієнт кореляції становить -0,87 (рівень статистичної надійності $p<0,001)$. Тобто зростання обсягів інвестицій у розрахунку на душу населення впливало на зниження рівня безробіття серед молоді (головним чином за рахунок створення нових робочих місць). Показники, що характеризують рівень фінансової спроможності населення (середньомісячна заробітна плата, наявні доходи та витрати населення в розрахунку на одну особу), характеризуються середнім і нижчим за середній рівнем тісноти зв'язку (відповідно -0,49, -0,47 та -0,43). Це свідчить про менш значущий вплив фрінансової спроможності населення в цілому на рівень безробіття молоді.

При цьому показники залежності динаміки рівня молодіжного безробіття та інвестиційної привабливості й фінансової спроможності населення мають суттєві міжрегіональні відміни. Найістотнішим є вплив інвестиційної привабливості (коефріцієнт кореляції у межах від -0,8 до -0,9) у Запорізькій та Харківській областях. У переважній більшості регіонів цей показник має середні та вище середнього значення. Натомість, у Вінницькій, Волинській,
Івано-Франківській, Полтавській, Сумській та Одеській областях залежність між рівнем інвестиційної привабливості та рівнем молодіжного безробіття слабко виражена.

Щодо впливу фрінансової спроможності населення на динаміку безробіття серед молоді, то найістотнішим він $€$ у Київській, а також Львівській і Чернівецькій областях (всі три показники фрінансової спроможності населення мають тісноту зв'язку із рівнем безробіття молоді понад -0,6). Дещо менш виражений зв'язок характерний для Івано-Франківської, Миколаївської, Одеської, Харківської, Сумської, Житомирської та Черкаської областей. У решті регіонів вплив цього фактора $є$ слабшим, а у Вінницькій, Кіровоградській, Волинській, Дніпропетровській та Полтавській областях практично не відслідковується.

Таким чином, величина відносних (на душу населення) показників інвестиційної привабливості території та фрінансової спроможності населення не визначає ситуацію на ринку праці молоді, а отже й її міграційні настрої. Також не можна вести мову про істотні відмінності між регіонами залежно від їхньої господарської спеціалізації.

Висновки. Для України характерна суттєва регіональна диференціація економічних чинників безробіття та міграції молоді у 2000-х роках. IIÏ особливістює концентрація найвищих доходів та інвестиційно-інноваційної діяльності в кількох регіонах із високим рівнем соціально-економічного розвитку. Поглиблення розриву фрінансових індикаторів регіонального розвитку та посилення негативних соціально-економічних процесів у регіонах, які отримують незначні обсяги інвестицій в основний капітал для розвитку інноваційних галузей економіки, створення нових робочих місць, і надалі спонукатиме молодь до пошуку кращих умов життя та працевлаштування за межами таких регіонів, в обласному центрі чи за кордоном.

Показники залежності динаміки рівня молодіжного безробіття та інвестиційної привабливості й фінансової спроможності населення характеризуються середнім і нижчим за середній рівнем тісноти зв'язку та мають суттєві міжрегіональні відміни. Проведений кореляційний аналіз підтвердив, що вплив економічних факторів $€$ більш складним та, імовірно, пов'язаний із конкретними стратегіями місцевої влади щодо розв'язання проблем молодіжного безробіття. Тому навіть зростання інвестиційної привабливості та фрінансової спроможності населення не гарантує послаблення міграційного відтоку молоді з країни. 
Негативними наслідками молодіжного безробіття в Україні стали міграція кваліфікованої молоді за кордон на навчання та роботу і пов'язане з цим зниження рівня народжуваності, поширення бідності й соціальних негараздів серед молоді [4]. При цьому в міграціях молоді з України в останні роки спостерігається їхня диверсифікація, трансформація паттернів і розмивання границь між різними типами мобільності [19].

Список використаних джерел

1. Державна служба статистики України [Електронний ресурс]. - Peжим доступу: http://www.ukrstat.gov.ua.

2. Лібанова Е. М. Зовнішні трудові міграції українців: масштаби, причини, наслідки / Е. Лібанова // Демографія та соціальна економіка. 2018. - № 2 (33). - С. 11-26.

3. Географія праці: сучасні концепти та ринки праці регіонів / К. В. Мезенцев, Н. І. Мезенцева, І. О. Мостова, В. С. Сайчук: навч. посіб. - Київ: ВПЦ "Київський університет", 2014. - 190 с.

4. Мезенцев К. В. Міграційна поведінка студентської молоді: шлях до кар'єри за кордоном чи ситуативна можливість самореалізації? / К. В. Мезенцев, Н. І. Мезенцева // Регіон-2018: пошук стратегії оптимапьного розвитку - Харків, 2018 - С. 33-37.

5. Міграція в умовах трансформації регіональних ринків праці України: механізми регулювання / наук. ред. У. Я. Садова. - Львів, 2019. - 263 c.

6. Наукова та інноваційна діяльність в Україні: статист. зб. / відп. ред. М. С. Кузнєцова. - Київ: ДП "Інформаційно-видавничий центр Держстату України", 2018. - 88 с.

7. Паренюк В. А. Регіональна диференціація безробіття молоді в Україні // Регіональні проблеми України: географічний аналіз та пошук шляхів вирішення : зб. наук. пр. - Херсон, 2019. - С. 172-175

8. Приймак В. Міграційна привабливість регіонів України / В. Приймак, О. Голубник, Н. Шинкар // Україна: аспекти праці. - 2007. - № 1. С. $19-24$.

9. Семенова Л. Ю. Проблеми та перспективи розвитку молодіжного ринку праці в Україні / Л. Семенова // Вісн. Академії митної служби Украіни. Серія: Економіка. - 2015. - № 2. - С. 119-124.

10. Соціальна географія : підручник / за ред. Л. Нємець, К. Мезенцева. - Київ: Фенікс. - 304 с.

11. Українська міграція в умовах глобальних і націонапьних викликів XXI століття / наук. ред. У. Я. Садова. - Львів, 2019. - 110 с.

12. Українське "покоління Z": цінності та орієнтири. Результати загальнонаціонального опитування / Д. Гайдай, К. Зарембо та ін. - Київ: Центр "Нова Європа", 2017. - 135 с.

13. Українське суспільство: міграційний вимір: нац. доповідь / редкол. С. І. Пирожков та ін. ; авт. кол. С. Ю. Аксьонова, В. П. Антонюк, О. А. Банчук та ін. - Київ, 2018. - 396 с

14. Ager A. Understanding Integration: A Conceptual Framework / A. Ager, A. Strang // Journal of Refugee Studies. - 2008. - Vol. 21(2). P. $166-191$

15. Agunias D. R., Newland K. Circular Migration and Development: Trends, Policy Routes, and Ways Forward [Електронний ресурс]. - Режим доступу: https://www.migration policy.org/research/circular-migration-anddevelopment-trends-policy-routes-and-ways-forward

16. Bauer T., Zimmermann K. F. Assessment of possible migration pressure and its labor market impact following EU enlargement to Central and Eastern Europe // A study for the Department of Education and Employment, UK. IZA Research Report, 1999, №. 3 [Електронний ресурс]. - Режим доступу: http://legacy.iza.org/en/webcontent/ publications/reports/report_pdfs/ report pdfs/iza report 03.pdf

17. Engbersen G. Migration transitions in an era of liquid migration: Reflections on Fassmann and Reeger // M. Okólski (ed.), Europe: The Continent of Immigrants: Trends, Structures and Policy Implications. Amsterdam: Amsterdam University Press, 2011. - P. 91-105.

18. General and regional statistics. European Commission. Eurostat [Електронний ресурс]. - Режим доступу: http://ec.europa.eu/eurostat/ data/database.

19. Grzymala-Kazłowska A. From drifting to anchoring. Capturing the experience of Ukrainan migrants in Poland / A. Grzymala-Kazłowska, A. Brzozowska // Central and Eastern European Migration Review. - 2017. Vol. 6(2) - P. 103-122

20. Mezentsev K. Ukraine: stable outflow and changing nature / K. Mezentsev, G. Pidgrushnyi // Á. Erőss \& D. Karacsonyi (Eds.). Discovering migration between Visegrad countries and Eastern Partners. Budapest: HAS RCAES Geographical Institute, 2014. - P. 191-211.

21. Taylor J. E. Differential migration, networks, information and risk / J. E. Taylor // O. Stark (ed.), Research in Human Capital and Development.
- Vol. 4: Migration, Human Capital, and Development. JAI Press, Greenwich, CT, 1986

22. Wickramasinghe $A$. International migration and migration theories A. Wickramasinghe, W. Wimalaratana // Social Affairs. - 2016. - Vol. 1(5). P. 22-24

23. World Employment and Social Outlook 2016 - Trends for Youth. International Labour Organization. Geneva: ILO, 2016.

24. Zlotnik H. The theories of international migration / H. Zlotnik // Pape for the Conference on International Migration: Challenges for European Populations. - Bari, Italy, 25-27 June, 1998.

\section{References}

1. Derzhavna sluzhba statystyky Ukrainy [Elektronniy resurs]. Rezhym dostupu: http://www.ukrstat.gov.ua.

2. Libanova E. M. Zovnishni trudovi mihratsii ukraintsiv: masshtaby, prychyny, naslidky // Demohrafiia ta sotsialna ekonomika, 2018, № 2 (33).

3. Mezentsev K. V., Mezentseva N. I., Mostova I. O., Saichuk V. S. Heohrafiya pratsi: suchasni kontseptsii ta rynky pratsi regioniv: Navch. posibnyk. Kyiv: VPTs "Kiyivskyi universytet", 2014. $190 \mathrm{~s}$.

4. Mezentsev K. V., Mezentseva N.I. Mlgratsiina povedinka studentskoyi molodi: shlyah do kariery za kordonom chy sytuatyvna mozhlyvist samorealizatsii? // Region-2018: poshuk stratehii optymalnoho rozvytku. Kharkiv, 2018. S. 33-37.

5. Mihratisia $v$ umovakh transformatsii rehionalnykh rynkiv pratsi Ukrainy: mekhanizm rehuliuvaniia / Nauk. red. U. I. Sadova. Lviv, 2019. 263 s.

6. Naukova ta innovatsiina diialnist v Ukraini: statystychyi zbirnyk. Kyiv: DP "Informatsiino-vydavnycjhyi tsentr Derzhstatu Ukrainy", 2018. 88 c.

7. Parenyuk V.A. Rehionalna dyferentsiatsiia bezrobittia molodi v Ukraini // Rehionalni problemy Ukrainy: heohraflchnyi analiz ta poshuk shliahiv vyrishennia. Zb. nauk. prats. Kherson, 2019. S. 172-175.

8. Pryimak V., Holubnyk O., Shynkar N. Mihratsiinpryvablyvist rehionov Ukraiiny // Ukraiina: aspektypratsi, 2007, № 1. C. 19-24.

9. Semenova L. Yu. Problemy ta perspektyvy rozvytku molodizhnoho rynku pratsi v Ukraini // Visnyk Akademii mytnoi sluzhby Ukrayiny. Seriya: Ekonomika, 2015, № 2. S. 119-124.

10. Sotsialna geografiya: Pidruchnyk / Za red. L. Niemets, K. Mezentseva. Kyiv: Feniks, $304 \mathrm{~s}$.

11. Ukraiinska mihratsiia $v$ umovakh hlobalnykh i natsionalnykh vyklykivXXI stolittia / Nauk. red. U. I. Sadova. Lviv, 2019. 110 s.

12. Ukraiinske pokolinnia $Z$ : tsinnosti ta orientyry. Rezultaty zahalnonatsionalnoho opytuvannia. Kyiv, 2017. $135 \mathrm{~s}$.

13. Ukraiinske suspilstvo: mihratsiinyi vymir: Nats. Dopovid. Kyiv, 2018. $396 \mathrm{~s}$.

14. Ager A., Strang A. Understanding Integration: A Conceptual Framework // Journal of Refugee Studies, 2008, Vol. 21(2). P. 166-191.

15. Agunias D. R., Newland K. Circular Migration and Development: Trends, Policy Routes, and Ways Forward. [Електронний ресурс]. Режим доступу: https://www.migration policy.org/research/circular-migration-anddevelopment-trends-policy-routes-and-ways-forward

16. Bauer T., Zimmermann K. F. Assessment of possible migration pressure and its labor market impact following EU enlargement to Central and Eastern Europe // A study for the Department of Education and Employment, UK. IZA Research Report, 1999, No. 3. Режим доступу: http:// legacy.iza.org/en/webcontent/publications/reports/report_pdfs/report_pdfs/ iza_report_03.pdf

17. Engbersen G. Migration transitions in an era of liquid migration: Reflections on Fassmann and Reeger // M. Okólski (ed.), Europe: The Continent of Immigrants: Trends, Structures and Policy Implications. Amsterdam: Amsterdam University Press, 2011. P. 91-105.

18. General and regional statistics. European Commission. Eurostat [Електронний ресурс]. Режим доступу: http://ec.europa.eu/eurostat/ data/database.

19. Grzymala-Kazłowska A., Brzozowska A. From drifting to anchoring. Capturing the experience of Ukrainan migrants in Poland. Central and Eastern European Migration Review, 2017, Vol. 6(2). P. 103-122.

20. Mezentsev K., Pidgrushnyi G. (2014). Ukraine: stable outflow and changing nature // Á. Erőss \& D. Karacsonyi (Eds.), Discovering migration between Visegrad countries and Eastern Partners. Budapest: HAS RCAES Geographical Institute, 2014. P. 191-211.

21. Taylor J. E. Differential migration, networks, information and risk I Stark (ed), Research in Human Capital and Development, Vol 4 Migration, Human Capital, and Development. JAI Press, Greenwich, CT, 1986.

22. Wickramasinghe A., Wimalaratana W. International migration and migration theories // Social Affairs, 2016, Vol. 1(5). P. 22-24.

23. World Employment and Social Outlook 2016 - Trends for Youth. International Labour Organization. Geneva: ILO, 2016.

24. Zlotnik $\mathrm{H}$. The theories of international migration. Paper for the Conference on International Migration: Challenges for European Populations, Bari, Italy, 25-27 June, 1998.

Надійшла до редколегії 10.10.20

К. Мезенцев, д-р геогр. наук, проф.,

Н. Провотар, канд. геогр. наук, доц.

В. Паренюк, асп.

Киевский национальный университет имени Тараса Шевченко, Киев, Украина

Миграционные намерения молодежи связаны с ситуацией на молодежном рынке труда, доходами населения и инвестиционно-инновационными процессами. Такие экономические факторы, в свою очередь, обусловливают ситуацию на региональных рынках труда. Трудовая и образовательная миграция молодежи несут угрозу потери квалифицированного населения трудоспособного возраста и, 
следовательно, дальнейший демографический кризис, дефицит квалифицированных кадров на региональных рынках труда в Украине. В статье представлены результаты исследования экономических факторов пространственной дифференциации безработицы молодежи в Украине в контексте ее миграционных настроений. Информационной базой исследования являются данные Государственной службы статистики Украины, в частности показатели уровня безработицы молодежи, среднемесячной заработной платы, доходов и расходов населения на одного жителя, их структуры, объемов инвестиций в основной капитал на душу населения по регионам Украины за период 2000-2018 г2. Методом рангов выделены группы регионов Украины с разным уровнем доходов и объема инвестиций в основной капитал на одного жителя, разработаны картосхемы группировки регионов Украины. Город Киев и столичная область неизменно лидируют как по инвестиционным показателям, так и по доходам и расходам. Стабильно отставали в 2001-2018 г2. регионы Западной Украины - Ривненская, Тернопольская, Черновицкая и Закарпатская области. Корреляционный анализ выявил зависимость уровня безработицы молодежи от инвестиционной привлекательности и финансовой состоятельности населения (включая показатели среднемесячной заработной платы, доходов и расходов на душу населения) в Украине. Однако такая зависимость характеризуется значительными региональными различиями, которые нельзя объяснить уровнем развития, расположением или специализацией регионов. Определено, что влияние экономических факторов является более сложным и, вероятно, связано с конкретными стратегиями местной власти по решению проблем молодежной безработицы. Поэтому даже рост инвестиционной привлекательности и финансовой состоятельности населения не гарантирует ослабление миграционного оттока молодежи из страны.

Ключевые слова: безработица молодежи, рынок труда, миграционные намерения, региональная дифференциация, Украина.

K. Mezentsev, DSc, Professor,

N. Provotar, PhD Geography, Assistant Professor,

V. Parenyuk, PhD student

Taras Shevchenko National University of Kyiv, Kyiv, Ukraine

\section{ECONOMIC FACTORS OF REGIONAL DIFFERENTIATION OF YOUNG PEOPLE'S} UNEMPLOYMENT AND MIGRATION INTENTIONS IN UKRAINE

Migration intentions of young people are related to the youth labour market situation, incomes, investment attractiveness and innovations. Such economic factors, in turn, determine the situation on regional labour markets. Labour and educational migration of young people threaten to lose the working-age high-skilled population, and therefore a further demographic crisis, shortage of skilled labour and qualified personnel in the regional labour markets in Ukraine.This article discusses the study results of economic factors of spatial variation of young people's unemployment in Ukraine in the context of their migration intentions. The study is based on the State Statistics Service of Ukraine official data, in particular, youth unemployment rate, average monthly wages, incomes and expenses per capita, their structure, and investments in fixed assets per capita by regions of Ukraine during 2000 2018. Using the rank method and mapping, Ukraine's regions were classified by the income levels and investments in fixed assets per capita. The city of Kyiv and the metropolitan region are invariably leaders in terms of both investment performance and income and expenditure. Steadily lagging behind in 2001-2018 were the western Ukrainian regions - Rivne, Ternopil, Chernivtsi, and Zakarpattia oblasts. A correlation analysis revealed the youth unemployment rates' dependence from the investment attractiveness and financial capability (including average monthly wages, incomes and expenses per capita) in Ukraine. However, such dependence is characterized by significant regional differences, which cannot be explained by the level of development, location or specialization of regions. It was determined that the influence of economic factors is more complicated and possibly is associated with specific local authorities' strategies to combat the youth unemployment. Therefore, even an increase in investment attractiveness and financial capability of population does not guarantee an overcoming or reducing of young people outflow from the country.

Keywords: youth unemployment, labour market, migration intentions, regional differentiation, Ukraine.

http://doi.org/10.17721/1728-2721.2020.76-77.3

УДК 911.3

І. Смирнов, д-р геогр. наук, проф.,

О. Любіцева, д-р геогр. наук, проф. ORCID iD: 0000-0002-8508-9395

Київський національний університет імені Тараса Шевченка, Київ, Україна,

Н. Бєлоусова, канд. геогр. наук, доц. Київський національний авіаційний університет, Київ, Україна

\section{ПОЛЬСЬКЕ РОЗТОЧЧЯ: ПОТЕНЦІАЛ УКРАЇНСЬКО-ПОЛЬСЬКОї СПІВПРАЦІ У СФЕРІ РЕКРЕАЦІЇ ТА ТУРИЗМУ}

Розкрито рекреаційно-туристичний потенціал Розточчя - регіону на південному сході Польщі, прикордонному з Україною, його туристичну спеціалізацію та можливості розвитку співробітництва з Україною у сфері рекреації й туризму. Досліджено ресурсну базу регіону Розточчя для формування його сучасної туристичної спеціалізації, зокрема гастрономічного, міського, сільського зеленого, пішохідного, літературного, історико-пізнавального та військового різновидів туризму. Розкрито специфіку гастрономічного туризму регіону, який базується на доволі специфічній сільськогосподарській базі Розточчя. Бідна природа Полісся та господарська нерозвиненість у минулому зумовили низький рівень життя місцевого населення, що і відбилося на його харчових преференціях. Основні інгредієнти страв кухні Розточчя - каші, сири, кисла капуста і горох, але нині вони у великій ціні через їхні оздоровчо-корисні властивості. Зазначено, що серед смаколиків Розточчя відсутні страви із м'яса та солодощі, що відображає рівень життя й харчування населення цього регіону в минулому. Так, найвідоміший розточанський "делікатес" - пляцек із цибулею (польською - цебуляж), але тепер ия страва місиевої бідноти стала загальнопольською гордістю, оскільки це був перший продукт Люблінського воєводства, що отримав Захищене географічне зазначення Європейського союзу. Сьогодні він є першим продуктом, який рекомендується туристам по приїзді до Розточчя. Цікаві й інші страви місцевої кухні - розточанський борщ, який місцеві мешканці називають українським, коржики з борошна і води, деруни з тіста з додаванням картоплі та яєць, місцеві пельмені 3 начинкою з гречаної каші та сиру, розточанські котлети, які роблять не із м'яса, а з гречаної каші, сиру й картоплі. Простий $і$ здоровий характер кухні Розточчя включав обмеження на вживання солодощів. Із асортиментом гастрономії Розточчя можна ознайомитись на місцевих гастрономічних фестивалях, до яких належать: Галицький ярмарок "Смаки Розточчя" у м. Нароль, фестиваль локального продукту в м. Замость, Люблінські зустрічі з мисливською традицією і культурою у м. Звєжинець, фестиваль кресової їжі в м. Башня Дольна тощо. Розкрито туристичні ресурси основних міст Розточчя - Замостя, Томашува-Любельського, Щебжешина. Запропоновано маршрути військового та велотуризму на основі відвідання укріплень так зв. Лінії Молотова, які збереглися у значній кількості на Розточчі .

Ключові слова: Польське Розточчя, туристичні ресурси, гастрономічний туризм, міьский туризм, літературний туризм, військовий туризм, Лінія Молотова.

Постановка наукової проблеми. Розточчя - погорбований лісистий масив Подільської височини на українсько-польському пограниччі. Воно є своєрідним "зеленим мостом" довжиною 200 км при ширині 20-30 км, що з'єднує Західну Україну (Львівська область) і Східну
Польщу (Люблінське воєводство). Українській частині Розточчя присвячено доволі численні географрічні та туристичні роботи, наприклад, праця В. І. Гетьмана [1]. Тут знаходиться Яворівський національний природний парк. Польська частина Розточчя, яка міститься на південному 